\title{
Properties of the Endopolygalacturonase Secreted by Rhizopus stolonifer
}

\author{
By A. S. TRESCOTT* AND J. TAMPION \\ Department of Life Sciences, The Polytechnic of Central London, London $W_{\mathrm{I}} M 8 J S$
}

(Received 25 June 1973; revised 30 August 1973)

SUMMAR Y

The endopolygalacturonase secreted by Rhizopus stolonifer Ehr. ex Fr. in vivo during infection of strawberries of the cultivar 'Cambridge Favourite' was extracted with a solution of sodium chloride and partially purified by gel filtration and ion-exchange chromatography. Partial purification removed $99.8 \%$ of the contaminating uronide materials, but the enzyme yield was reduced to $56 \%$ and the specific activity was increased only 2.5 times. The partially purified enzyme exhibited maximum stability at $\mathrm{pH} 4.0$ to 6.0 and optimal activity at $\mathrm{pH} 4.6$ to 4.8 . A linear thermal-inactivation pattern between 30 and $50^{\circ} \mathrm{C}$ was demonstrated and complete and irreversible inactivation was achieved by heating to $60^{\circ} \mathrm{C}$ for 20 min. Enzyme activity was inhibited by $20 \%$ or less by a range of enzyme inhibitors and cations, with $87 \%$ inhibition occurring in the presence of $\mathrm{IO}^{-3} \mathrm{M}-\mathrm{Hg}^{++}$. The molecular weight of the enzyme was calculated as 60000 , and the sedimentation and diffusion data suggested that the enzyme molecule has a high degree of asymmetry.

\section{INTRODUCTION}

Pectolytic enzymes are secreted by a wide range of micro-organisms and these enzymes are of some importance during the infection of plant host tissues (Wood, 1955, 1960; Bateman \& Millar, 1966). Rhizopus species are responsible for many soft-rot diseases and some have been implicated in the disintegration of sulphited strawberries (Dakin \& Tampion, I968; Trescott, I97I).

The production in vitro of endopolygalacturonase (poly- $\alpha$-1,4-galacturonide glycanohydrolase, EC. 3.2.I. I5) by Rhizopus stolonifer Ehr. ex Fr. has been investigated by Cappellini (I966), and production both in vitro and in vivo has been studied by Srivastava, Echandi \& Walker (I959). Methods for the partial purification of endopolygalacturonases secreted by various fungi have also been investigated (Bateman, 1968; Fielding \& Byrde, I969; Barash \& Eyal, I970; Kumari \& Sirsi, 1971), but there is relatively little information available on the purification and properties of the endopolygalacturonase secreted by $R$. stolonifer.

\section{METHODS}

Culture. Rhizopus stolonifer was obtained from the Commonwealth Mycological Institute (IMI90609 (+) strain) and was maintained on malt agar (Oxoid Ltd) with subcultures stored at $4{ }^{\circ} \mathrm{C}$. As the initial studies were concerned with the disintegration of sulphited strawberries, the fungus was grown on fresh strawberry fruits of the cultivar 'Cambridge Favourite'. The fruit was obtained from East Malling Research Station, Kent, and was collected from the field. After discarding damaged, over-ripe and infected fruits, the calyces

* Present address: The Department of Applied Chemical and Biological Sciences, The Polytechnic, Queensgate, Huddersfield HDI 3DH. 
were removed from the remaining strawberries which were then weighed into batches of approx. $400 \mathrm{~g}$. The individual fruits in each batch were inoculated with a sporulating culture of the fungus via a small wound made with a sterile needle in the cavity left by removal of the calyx. Each batch of inoculated fruit was placed in the upper half of a polythene bag which had been taped to a sloping surface; the fruit was kept in this position by means of a piece of tape stuck across the bag. The culture bags were loosely closed with paper clips which reduced the risks of aerial contamination. Incubation in a sloping position ensured that the fruit did not become immersed in the relatively large volume of exuded liquid. After $48 \mathrm{~h}$ the cultures were transferred to clean polythene bags which were then heatsealed along their openings. Groups of four such bags were placed inside larger polythene bags, which were also heat-sealed, before being stored at $-25^{\circ} \mathrm{C}$.

Preparation of crude enzyme extracts. Batches of $800 \mathrm{~g}$ of infected fruit were crushed while still frozen and mixed with $100 \mathrm{ml}$ of a $10 \%(\mathrm{w} / \mathrm{v})$ sodium chloride solution. After standing for $30 \mathrm{~min}$ at room temperature, the slurry was squeezed through several layers of nylon gauze and the cloudy filtrate kept on crushed ice. The residual material was extracted with a similar volume of sodium chloride solution and the filtrates pooled. The combined filtrates were then centrifuged at $4{ }^{\circ} \mathrm{C}$ for $20 \mathrm{~min}$ at $2500 \mathrm{~g}$ and the clear supernatant decanted. The clear extract was then filtered under suction through glass-fibre filter discs (Whatman Ltd) and diluted to $800 \mathrm{ml}$ with distilled water. Precipitation of the enzyme was achieved by mixing the filtrate with cold $\left(-10{ }^{\circ} \mathrm{C}\right)$ acetone to give a final acetone concentration of $80 \%(\mathrm{v} / \mathrm{v})$. The precipitate was allowed to settle overnight at $4{ }^{\circ} \mathrm{C}$ and the supernatant liquid decanted and discarded. The precipitate was washed with $50 \mathrm{ml}$ of cold acetone and then either air dried, crushed and stored at $4{ }^{\circ} \mathrm{C}$ as an acetone powder preparation, or dissolved in $50 \mathrm{ml}$ of either citrate-phosphate buffer $\left(\mathrm{pH}_{4} \cdot 8\right)$ or distilled water.

\section{Partial purification procedures}

Dialysis. Crude enzyme preparation, in buffer at $\mathrm{pH} 4 \cdot 8$, was dialysed against a large volume of buffer at $4{ }^{\circ} \mathrm{C}$ for $24 \mathrm{~h}$ before being assayed for enzyme activity and soluble protein and total uronide content.

Re-precipitation. A crude enzyme preparation was re-precipitated with cold acetone, the precipitate washed with acetone and then dissolved in buffer and assayed. A similar sample of crude enzyme preparation was re-precipitated with cold absolute ethanol, washed with ethanol, dissolved in buffer and assayed. Ammonium sulphate (B.D.H. Ltd) was added to a third sample of crude enzyme preparation until the solution was just saturated at $4{ }^{\circ} \mathrm{C}$. After standing for $2 \mathrm{~h}$ at $4{ }^{\circ} \mathrm{C}$ the precipitate was recovered by centrifugation, dissolved in buffer and dialysed for $2 \mathrm{~h}$ at $4{ }^{\circ} \mathrm{C}$ before being assayed.

Gel filtration. Gel filtration was done using Sephadex G 75 (Pharmacia AB, Uppsala, Sweden). The gel was allowed to swell in distilled water for $12 \mathrm{~h}$ at room temperature before being packed into a glass chromatography column (Pharmacia AB, type $K 25 / 45$, internal dimensions $2.5 \times 45 \mathrm{~cm}$ ). The gel bed was equilibrated with distilled water by washing at a flow rate of $55 \mathrm{ml} / \mathrm{h}$ for $24 \mathrm{~h}$; the stabilized bed had a total volume $\left(V_{t}\right)$ of $\mathrm{I} 8 \mathrm{I} \cdot 7 \mathrm{ml}$ and a void volume $\left(V_{v}\right)$ of $55 \mathrm{ml}$ as determined with dextran blue elution (Pharmacia AB). Samples of $20 \mathrm{ml}$ of crude enzyme preparations in distilled water were applied to the column and the enzyme was eluted with distilled water at a flow rate of $55 \mathrm{ml} / \mathrm{h}$. The collection of fractions $(5 \mathrm{ml} \pm 0.5 \mathrm{ml})$ was begun when half the sample was judged to have entered the bed. Samples of alternate fractions were taken for analysis.

Ion-exchange chromatography. This was done with Ecteola-cellulose (Cellex E; Bio-Rad Laboratories, California, U.S.A.). The material was suspended in distilled water and the 
fines discarded. The remaining material was then successively washed with $\mathrm{O} \cdot \mathrm{I} \mathrm{M}-\mathrm{NaOH}$, $\mathrm{O} \cdot \mathrm{I} \mathrm{M}-\mathrm{K}_{2} \mathrm{HPO}_{4}$ and distilled water before being packed into a glass chromatography column (Pharmacia AB, type K I5/25, internal dimensions $\mathrm{I} \cdot 5 \times 25 \mathrm{~cm}$ ). The bed was stabilized by washing with distilled water at a flow rate of $30 \mathrm{ml} / \mathrm{h}$ for $\mathrm{I} 2 \mathrm{~h}$. Enzyme samples were applied to the column in $2.0 \mathrm{ml}$ of distilled water and eluted initially with distilled water and then with $0 \cdot \mathrm{I} \mathrm{M}-\mathrm{NaCl}$ at a flow rate of $30 \mathrm{ml} / \mathrm{h}$. The collection of fractions was commenced when half the sample was judged to have entered the bed. Samples of each fraction were taken for analysis.

Storage of enzyme preparations. Enzyme samples which had been partially purified by both gel filtration and ion-exchange chromatography were freeze-dried and stored at $4{ }^{\circ} \mathrm{C}$.

\section{Molecular weight determinations}

Attempts to determine the molecular weight of the partially purified enzyme were made using the method described by Andrews (1964) and a range of polyacrylamide gels (Biogel PIoo to $\mathrm{P}_{300}$; Bio-Rad Laboratories, California, U.S.A.). The molecular weight and homogeneity of a purified enzyme sample were determined by a high-speed sedimentationvelocity method (Schachman, 1957). Samples containing 0.84 and $0.42 \mathrm{~g}$ of freeze-dried enzyme in $\mathrm{I} \mathrm{ml}$ of $0 . \mathrm{I} \mathrm{M}-\mathrm{NaCl}$ were centrifuged at $\mathrm{I} 87000 \mathrm{~g}$ in a Spinco Analytical Ultracentrifuge (Beckman Instruments).

\section{Analytical techniques}

Enzyme assays. Endopolygalacturonase was routinely assayed by a viscometric method, but the estimation of reducing sugar liberated by enzymic hydrolysis of the substrate was also used occasionally. All assays were done at $25{ }^{\circ} \mathrm{C}\left( \pm 0.5{ }^{\circ} \mathrm{C}\right)$ with sodium polypectate (Sigma Chemical Co., St Louis, Missouri, U.S.A.) as the substrate. (i) Viscometric method. Ostwald U-tube viscometers which had a flow time of about $30 \mathrm{~s}$ for II $\mathrm{ml}$ of distilled water were used. The substrate was dissolved in citrate-phosphate buffer (at $\mathrm{pH}_{4} .8$ unless otherwise stated) at concentrations such that I I $\mathrm{ml}$ of substrate solution had a flow time of 73 to $75 \mathrm{~s}$. For each assay, exactly I I $\mathrm{ml}$ of substrate solution were equilibrated to temperature in the viscometer and the flow time noted. At zero time, exactly $0.1 \mathrm{ml}$ of enzyme preparation was added to the viscometer and thoroughly mixed with the substrate. A series of flow-time readings was then taken, each beginning a known time after enzyme addition. The reciprocal of the specific viscosity $\left(\mathrm{I} / \eta_{\mathrm{ep}}\right)$ of the reaction mixture was calculated for each flow-time reading by using the viscosity conversions of Selby (I96I). These data were then plotted against the reaction times; individual reaction times were calculated as being the time in seconds after the addition of the enzyme, at which the flow-time reading was started, plus half of the actual flow-time reading. This simple modification was employed as a correction factor, since the viscosity of the reaction mixture changes continuously with time. Enzyme activity is expressed in arbitrary units $/ \mathrm{ml}$, one unit representing a change of $\mathrm{I} \cdot \mathrm{O} \times 1 \mathrm{O}^{-4}$ in the $\mathrm{I} / \eta_{\mathrm{sp}}$ of the reaction mixture in a period of $\mathrm{IOO} \mathrm{s}$. (ii) Reducing sugar method. Reaction mixtures consisted of $4.5 \mathrm{ml}$ of substrate solution ( $25 \mathrm{mg}$ of sodium polypectate in citrate-phosphate buffer, $\mathrm{pH}_{4.8}$ ) and $0.5 \mathrm{ml}$ of enzyme preparation. Samples of $0.1,0.2$ or $0.5 \mathrm{ml}$ were taken after appropriate incubation periods and reducing sugar determined by the method described by Nelson (1944). Optical densities were measured against appropriate blanks at $500 \mathrm{~nm}$ in a Unicam SP 600 spectrophotometer (Pye-Unicam Instruments, Cambridge). D-Galacturonic acid (B.D.H. Ltd) was used as a reference standard.

Total uronide estimations. Total uronide content of enzyme samples was determined by the method described by Bitter \& Muir (1962) after de-esterification of samples as suggested 
Table I. Partial purification of the endopolygalacturonase secreted by Rhizopus stolonifer

\begin{tabular}{|c|c|c|c|c|c|c|c|c|}
\hline Fraction & $\begin{array}{l}\text { Volume } \\
\text { (ml) }\end{array}$ & $\begin{array}{l}\text { Total } \\
\text { enzyme } \\
\text { activity } \\
\text { (units) }\end{array}$ & $\begin{array}{l}\text { Total } \\
\text { protein } \\
(\mathrm{mg})\end{array}$ & $\begin{array}{l}\text { Total } \\
\text { uronide } \\
\text { (mg) }\end{array}$ & $\begin{array}{l}\text { Yield } \\
(\%)\end{array}$ & $\begin{array}{l}\text { Specific } \\
\text { activity }\end{array}$ & $\begin{array}{l}\text { Purifi- } \\
\text { cation }\end{array}$ & $\begin{array}{c}\text { Retention } \\
\text { of } \\
\text { uronide } \\
(\%)\end{array}$ \\
\hline $\begin{array}{l}\text { Crude } \\
\text { enzyme }\end{array}$ & 20 & 50000 & 25.0 & 460 & 100 & 2000 & $1 \cdot 0$ & 100 \\
\hline $\begin{array}{l}\text { Dialysed } \\
\text { enzyme }\end{array}$ & 20 & 49600 & 24.08 & 456 & $99 \cdot 2$ & 2060 & I.03 & $99 \cdot 13$ \\
\hline $\begin{array}{l}\text { Acetone } \\
\text { ppt }\end{array}$ & 20 & 40000 & $20 \cdot 0$ & $360 \cdot 18$ & 80 & 2000 & $\mathrm{I} \cdot \mathrm{O}$ & $78 \cdot 3$ \\
\hline $\begin{array}{c}\text { Ethanol } \\
\text { ppt }\end{array}$ & 20 & 36000 & 18.0 & $312 \cdot 8$ & 72 & 2000 & $1 \cdot 0$ & $68 \cdot 0$ \\
\hline $\begin{array}{l}\text { Ammonium } \\
\text { sulphate } \\
\text { ppt }\end{array}$ & 20 & 10000 & $3 \cdot 4$ & $55 \cdot 2$ & 20 & 2940 & $\mathrm{I} \cdot 47$ & $12 \cdot 0$ \\
\hline $\begin{array}{l}\text { Sephadex } \\
\text { G } 75 \\
\text { (fractions } \\
8 \text { to 24) }\end{array}$ & 85 & 35300 & $7 \cdot 88$ & $28 \cdot 33$ & $70 \cdot 6$ & 4480 & $2 \cdot 24$ & $6 \cdot 16$ \\
\hline $\begin{array}{l}\text { Ecteola- } \\
\text { cellulose } \\
\text { (fractions } \\
2 \text { to } 6 \text { ) }\end{array}$ & 25 & 28000 & $5 \cdot 62$ & 0.94 & 56 & 4980 & $2 \cdot 49$ & 0.204 \\
\hline
\end{tabular}

by McComb \& McCready (1952). Extinction was measured against appropriate blanks at $530 \mathrm{~nm}$ with D-galacturonic acid as the reference standard.

Protein estimations. The soluble-protein content of enzyme samples was determined by the method of Lowry, Rosebrough, Farr \& Randall (I95I) with crystalline bovine serum albumin (B.D.H. Ltd) as the reference standard.

\section{RESULTS}

Growth of the fungus on fresh strawberries was both vigorous and prolific, with sporulation commencing after $24 \mathrm{~h}$. After $48 \mathrm{~h}$ incubation the cultures contained appreciable amounts of endopolygalacturonase and this remained stable during deep-freeze storage. Acetone-powder preparations were brownish and contained large amounts of contaminating uronide materials in addition to high enzyme activity. Ammonium sulphate precipitation of crude enzyme preparations removed much of the contaminating uronide material, but the specific activity and purification of the enzyme were only slightly increased while the yield was greatly reduced (Table I). Gel filtration separated the enzyme from the uronide material. Two distinct protein-rich peaks were obtained, the first containing all of the enzyme activity and relatively little uronide material (Fig. I). Fractions 8 to 24 were pooled and concentrated to a volume of $5 \mathrm{ml}$. A $2 \mathrm{ml}$ sample of this concentrate was applied to the Ecteola-cellulose column. Two elution peaks were obtained, the first containing all of the enzyme activity (Fig. 2). The partially purified endopolygalacturonase was found to have a broad $\mathrm{pH}$ optimum range, greatest activity being in the range $\mathrm{pH}_{4} \cdot 6$ to $4 \cdot 8$. Samples which had been held at ambient temperature $\left(2 \mathrm{I}{ }^{\circ} \mathrm{C}\right.$ approx.) for $20 \mathrm{~min}$ were found to be stable over a wide $\mathrm{pH}$ range with an optimum at $\mathrm{pH} 4 \cdot 0$ to $6 \cdot 0$. 


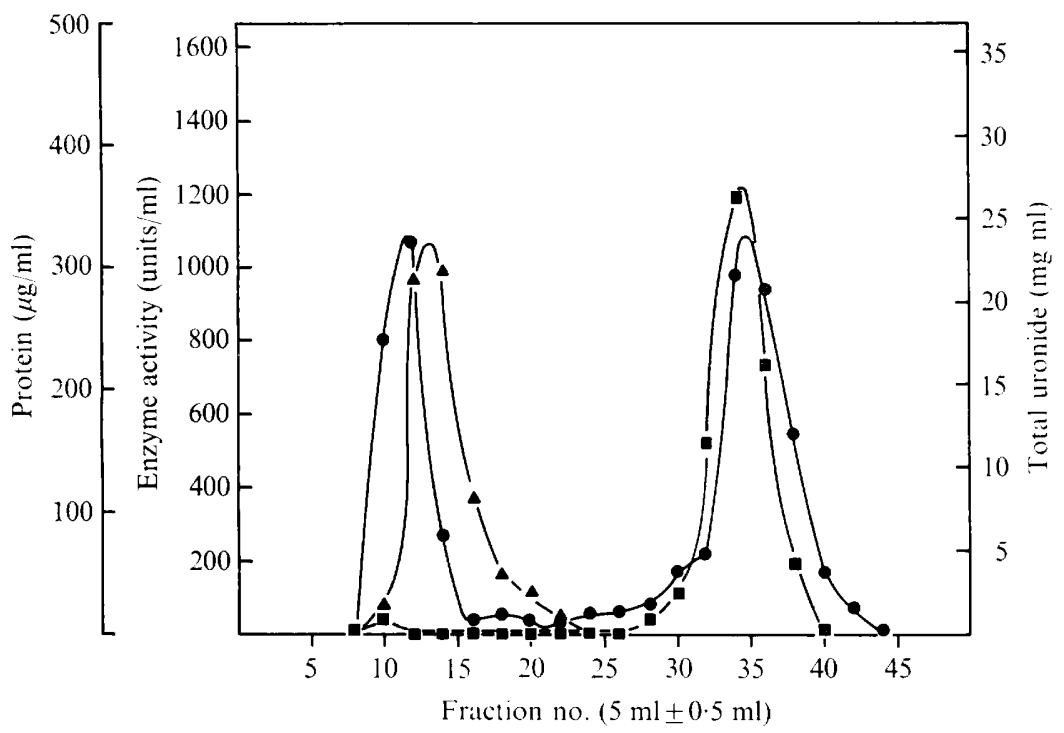

Fig. I. Elution diagram of crude endopolygalacturonase on Sephadex G 75 (20 ml crude enzyme extract applied to the column and eluted with distilled water at a flow rate of $55 \mathrm{ml} / \mathrm{h}$ ). 9 , Protein; $\boldsymbol{\Delta}$, endopolygalacturonase; $\boldsymbol{\nabla}$, uronide.

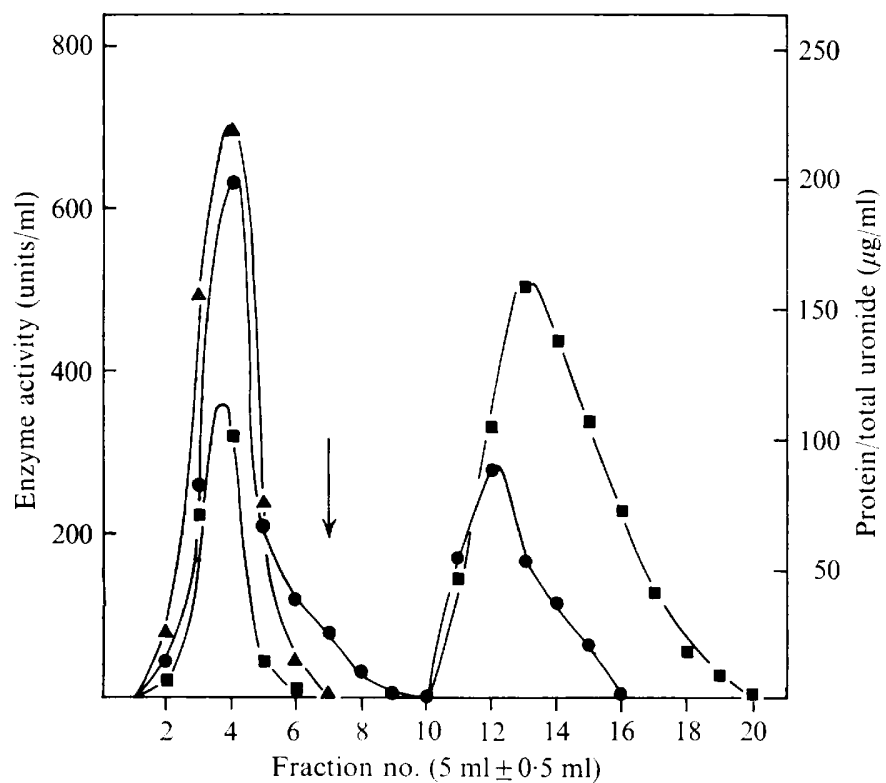

Fig. 2. Elution diagram of Sephadex G 75 purified enzyme from Ecteola-cellulose (sample applied to column and eluted with distilled water and then $\left.0^{\cdot} \mathrm{I} \mathrm{M}-\mathrm{NaCl}, \downarrow\right)$. $\boldsymbol{\bullet}$, Protein; $\boldsymbol{\Delta}$, endopolygalacturonase, $\mathbf{\square}$, uronide.

Samples of enzyme which had been held at optimal pH for 20 min showed a linear thermal-inactivation pattern over the range 30 to $50{ }^{\circ} \mathrm{C}$. Complete and irreversible inactivation was achieved by heating to $60^{\circ} \mathrm{C}$ for $20 \mathrm{~min}$. Exposure of the enzyme to the following cations, which were incorporated in the reaction mixtures as chlorides at concentrations of $\mathrm{IO}^{-3} \mathrm{M}$ and $\mathrm{IO}^{-4} \mathrm{M}$, caused less than $20 \%$ inhibition: $\mathrm{Ca}^{2+}, \mathrm{Mg}^{2+}, \mathrm{Pb}^{2+}, \mathrm{Cu}^{2+}, \mathrm{Fe}^{2+}, \mathrm{Na}^{+}$ 


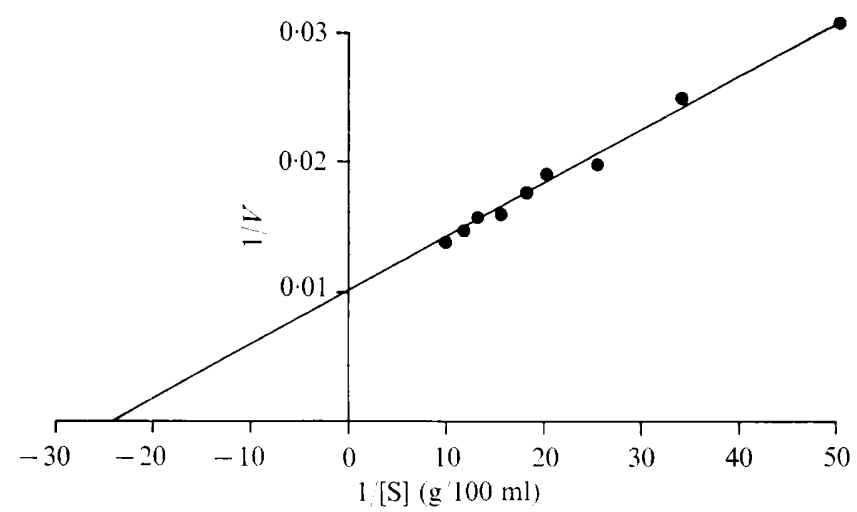

Fig. 3. Lineweaver-Burke plot to show the Michaelis-Menten dissociation constant of endopolygalacturonase.

Expt 1

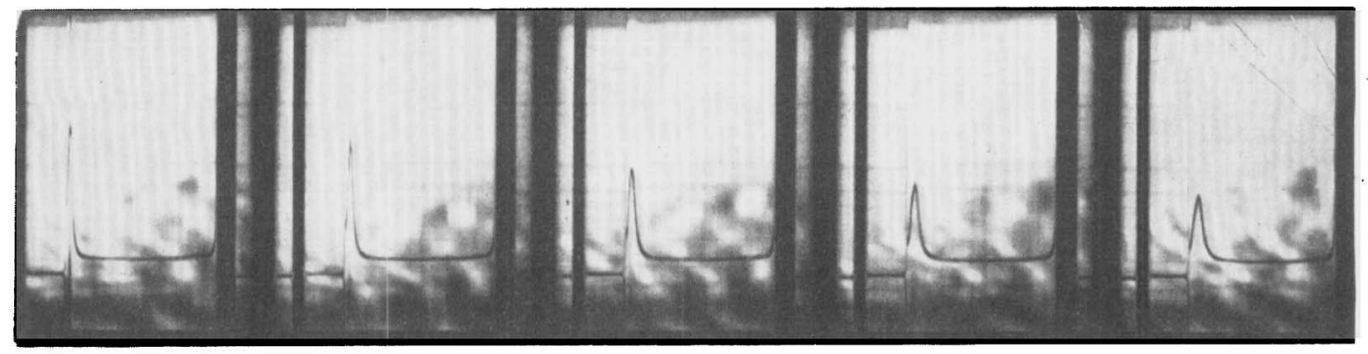

10

14

18

22

26

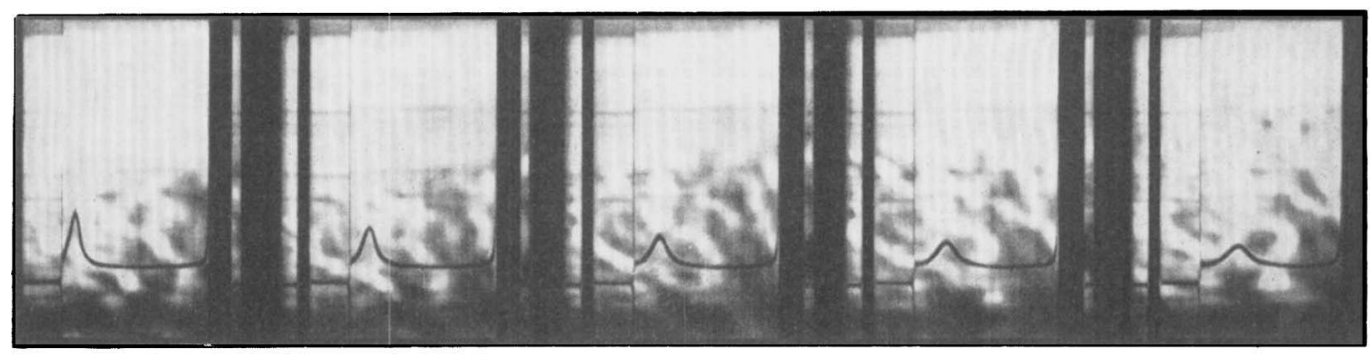

34

50

66

82

98

\section{Expt 2}

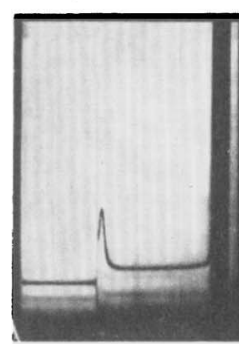

5

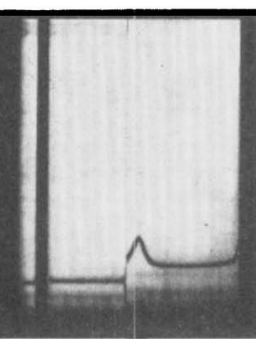

21

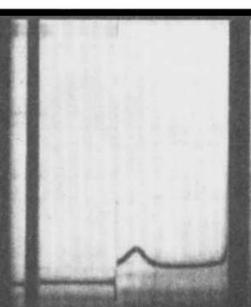

37

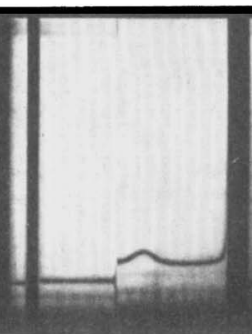

53

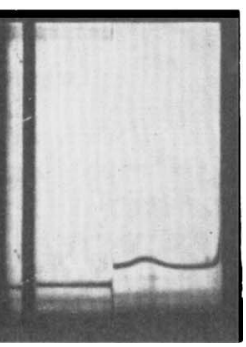

69

Fig. 4. Ultracentrifugation of partially purified endopolygalacturonase. Expt $\mathrm{I}: 0.84 \mathrm{~g}$ freeze-dried enzyme in $\mathrm{I} \mathrm{ml} \mathrm{O} \cdot \mathrm{I} \mathrm{M}-\mathrm{NaCl}$. Expt 2: $0.42 \mathrm{~g}$ freeze-dried enzyme in I ml O.I M-NaCl. The numbers indicate the time, in min, at which photographs were taken after the rotor had reached the operating speed. 
and $\mathrm{K}^{+}$. More than $20 \%$ inhibition was attained with $\mathrm{Mn}^{2+}$ at $\mathrm{IO}^{-3} \mathrm{M}(2 \mathrm{I} \%), \mathrm{Ba}^{2+}$ at $\mathrm{IO}^{-3} \mathrm{M}(25 \%), \mathrm{Hg}^{2+}$ at $\mathrm{IO}^{-3} \mathrm{M}(87 \%)$ and $\mathrm{Hg}^{2+}$ at $\mathrm{IO}^{-4} \mathrm{M}(57 \%)$. None of the cations tested enhanced activity.

Exposure of the enzyme to the following inhibitors, which were incorporated in the reaction mixtures at $1 \mathrm{I}^{-3} \mathrm{M}$ and $1 \mathrm{O}^{-4} \mathrm{M}$, caused less than $\mathrm{I} 8 \%$ inhibition: 2,4 -dinitrophenol, iodoacetic acid, cysteine, sodium azide, potassium cyanide, ethylenediamine tetra-acetic acid (disodium salt), 8-hydroxyquinoline, sodium diethyldithiocarbamate, and urea.

A $K_{m}$ value of $0.042 \%(\mathrm{w} / \mathrm{v})$ was obtained by using the reducing sugar estimation method with dilute (O.I to $0.02 \%$, w/v) substrate solutions (Fig. 3). Attempts to determine the molecular weight of endopolygalacturonase by molecular-exclusion chromatography were unsuccessful. The enzyme was consistently eluted in the void volume of the column, irrespective of the exclusion limit of the polyacrylamide gel used. Calibration data similar to those of Andrews (I 964) were obtained by using standard proteins of known molecular weight.

The two high-speed sedimentation-velocity determinations indicated the presence of a single symmetrical peak which gradually spread with time (Fig. 4). Sedimentation coefficients $\left(s_{20, \mathrm{w}}\right)$ of 2.6 and $3.26 \mathrm{~S}$ were obtained; the diffusion coefficient $(D)$ was calculated to be $4.4 \times 10^{-7} \mathrm{~cm}^{2} \mathrm{~s}^{-1}$. Taking the partial specific volume $(v)$ of the solute to be 0.75 , a mol. wt of approx. 60000 was calculated for the partially purified enzyme.

\section{DISCUSSION}

Rhizopus stolonifer secretes endopolygalacturonase soon after it has infected fresh strawberries, and this enzyme is known to be responsible for the disintegration of sulphited strawberries (Trescott, I97I). Gel filtration followed by ion-exchange chromatography of the crude enzyme was found to be the best of the methods investigated for partial purification, since $99.8 \%$ of the contaminating uronide material could be removed. However, the enzyme was consistently and completely eluted in the void volumes of gel columns, irrespective of both the nature and molecular exclusion limits of the gels used (dextran or polyacrylamide). A similar phenomenon has been reported by Bateman (I968) for the endopolygalacturonase secreted by Sclerotium rolfsii, who found that a small proportion of the enzyme was consistently eluted in the void volume.

The behaviour of the endopolygalacturonase secreted by Rhizopus stolonifer differed from that produced by Sclerotinia fructigena (Fielding \& Byrde, I969) since it could not be eluted in a sharp peak from Ecteola-cellulose with $0 \cdot \mathrm{I} \mathrm{M}-\mathrm{NaCl}$. The dissociation and recombination of endopolygalacturonase during ion-exchange chromatography has been reported by Swinburne \& Corden (1967). It is suggested that elution of the enzyme in the void volumes of gel columns is caused by association of the enzyme molecules themselves, or by association of the enzyme with residual uronide materials to form a high molecular weight complex. However, the symmetry of the enzyme molecule must not be ignored. The concentration dependence of the sedimentation coefficient suggests that the enzyme molecule has a high degree of asymmetry, and this may well differ considerably from the molecular symmetry of the proteins frequently used to calibrate gel columns for molecular weight determinations. The association of enzyme molecules or the high degree of asymmetry of the enzyme molecule may explain both the elution of the enzyme in the void volumes of gel columns and the differing estimates of the molecular weight of endopolygalacturonase found by other workers. The molecular weight of the endopolygalacturonase secreted by Sclerotium rolfsii has been estimated to be 28000 to 30000 (Bateman, 1968) and 
that produced by S. fructigena to be 38000 and 70000 (Fielding \& Byrde, I969). The approximate molecular weight of the enzyme secreted by $R$. stolonifer was calculated to be 60000 . The higher estimates of 60000 and 70000 are approximately double the lower estimates found by other workers, and this would appear to favour the association-dissociation concept.

The optimal $\mathrm{pH}$ range of activity ( $\mathrm{pH} 4.6$ to $4 \cdot 8$ ) is fairly typical of fungal endopolygalacturonase, while the stability of the enzyme produced by Rhizopus stolonifer is very similar to that of Sclerotinia fructigena (Fielding \& Byrde, 1969). The thermal inactivation pattern is similar to that of the polygalacturonase from Geotrichum candidum (Barash \& Eyal, 1970). No thermal activation was found above $60^{\circ} \mathrm{C}$ as reported by other workers (Fielding \& Byrde, I969; Kumari \& Sirsi, I97I). The Michaelis-Menten dissociation constant, although difficult to determine for practical reasons, was found to be $0.042 \%$, and this approximates closely to the value of $0.03 \%$ found by Jansen \& MacDonnell (I945).

This work was done in partial fulfilment of the requirements of the Ph.D. degree of the University of London. The authors thank Dr K. V. Shooter of Pollards Wood Research Station, The Chester Beatty Institute, for performing the two sedimentation-velocity experiments.

\section{REFERENCES}

ANDrews, P. (1964). Estimation of the molecular weight of proteins by Sephadex gel filtration. Biochemical Journal 91, 222-233.

Barash, I. \& Eyal, Z. (1970). Properties of a polygalacturonase produced by Geotrichum candidum. Phytopathology 60, 27-30.

Bateman, D. F. (1968). The enzymatic maceration of plant tissue. Netherlands Journal of Plant Pathology 74 (S I), 67-80.

Bateman, D. F. \& Millar, R. L. (1966). Pectic enzymes in tissue degradation. Annual Review of Phytopathology 4, II9-146.

Bitter, T. \& Muir, H. M. (I962). A modified carbazole uronic acid reaction. Analytical Biochemistry 4 , 330-334.

CAPPELlini, R. A. (1966). Growth and polygalacturonase production by Rhizopus stolonifer. Phytopathology 56, 734-737.

Dakin, J. C. \& TAMPION, J. (I968). Specific fungi as the causative agents of the disintegration of sulphited strawberries. Journal of Food Technology 3, 39-48.

Fielding, A. H. \& BYRDE, R. J. W. (1969). The partial purification and properties of endopolygalacturonase and $\alpha$-L-arabinofuranosidase secreted by Sclerotinia fructigena. Journal of General Microbiology $\mathbf{5}^{8}$, 73-84.

JANSEN, E. F. \& MACDonnel., L. R. (I945). Influence of methoxyl content of pectic substances on the action of polygalacturonase. Archives of Biochemistry 8, 97-I 12.

KumaRi, L. H. \& Sirsi, I. (I97I). Purification and properties of endopolygalacturonase from Ganoderma lucidum. Journal of General Microbiology 65, 285-290.

Lowry, O. H., Rosebrough, N. J., FarR, A. L. \& Randall, R. J. (I95I). Protein measurements with Folin phenol reagent. Journal of Biological Chemistry I93, 265-275.

McСomв, E. A. \& MCCready, R. M. (I952). Colorimetric determination of pectic substances. Analytical Chemistry 24, 1630-1632.

Nelson, N. (1944). A photometric adaptation of the Somogyi method for the determination of glucose. Journal of Biological Chemistry 153, 373-380.

Schachman, H. K. (1957). Ultracentrifugation, diffusion and viscometry. In Methods in Enzymology, vol. 4, pp. 32-103. Edited by S. P. Colwick and N. O. Kaplan. New York: Academic Press.

SELBY, K. (196I). The degradation of cotton cellulose by the extracellular cellulase of Myrothecium verrucaria. Biochemical Journal 79, 562-566.

Srivastava, D. N., Echandi, E. \& Walker, J. C. (I959). Pectolytic and cellulolytic enzymes produced by Rhizopus stolonifer. Phytopathology 49, I45-I48. 
Swinburne, T. R. \& Corden, M. E. (1967). Dissociation and recombination of a polygalacturonase complex during ion-exchange chromatography. Nature, London 213, 286-287.

TrescotT, A. S. (197I). A study of the enzymes secreted by Rhizopus stolonifer Ehr. ex Fr. which are responsible for the disintegration of sulphited strawberries (Fragaria 'Cambridge Favourite'). Ph.D. Thesis, London University.

WooD, R. K. S. (I955). Pectic enzymes secreted by pathogens and their role in plant infection. In Mechanisms of Microbial Pathogenicity, pp. 263-293. Edited by J. W. Howie and A. J. O'Hea. Cambridge University Press.

Wood, R. K. S. (1960). Pectic and cellulolytic enzymes in plant disease. Annual Review of Plant Physiology Ir, 299-322. 